\title{
No Ceará não tem disso não? Negacionismos e povos indígenas e negros na formação social do Ceará
}

\author{
There Isn't Any of that in Ceará, is There? \\ Negationism and the Black and Indigenous \\ People in the Social Formation of Ceará
}

\author{
Edson Holanda Lima Barboza* \\ Silviana Fernandes Mariz ${ }^{\star \star}$
}

\section{RESUMo}

$\mathrm{O}$ artigo analisa os esforços revisionistas recentemente empregados na obra $O$ Cearense Revelado, de Luís Santos (2020), além de abordagens da historiografia cearense que, por um lado, negam ou menosprezam a presença de negros no processo de formação social do Ceará e, por outro, reproduzem o discurso do desaparecimento dos povos indígenas como resultado da colonização portuguesa, considerando o cearense produto da miscigenação entre os portugueses vitoriosos e os indígenas eliminados. Ao destacar uma suposta predominância nórdica, a narrativa criada em $\mathrm{O} C e a-$ rense Revelado ultrapassa os limites de uma leitura revisionista, chegando a alcançar um viés negacionista, perspectiva bastante confortável para justificar hierarquias de poderes e saberes em um

\section{Abstract}

The article analyzes the revisionist efforts recently employed in the book $O$ Cearense Revelado, by Luís Santos (2020), as well as the Cearense historiographical approaches that, on the one hand, deny or belittle the presence of blacks in the process of social formation of Ceará and, on the other hand, reproduce the discourse of the disappearance of indigenous peoples as a result of the Portuguese colonization, considering the Cearense to be the product of miscegenation between the victorious Portuguese and the eliminated indigenous people. By highlighting a supposed Nordic predominance, the narrative created in $\mathrm{O} C e a-$ rense Revelado goes beyond the limits of a revisionist reading, reaching a negationist bias; a quite comfortable perspective to justify hierarchies of power and

\footnotetext{
* Universidade da Integração Internacional da Lusofonia Afro-Brasileira (UNILAB), Redenção, CE, Brasil. edsonholanda@unilab.edu.br <https://orcid.org/0000-0001-9248-6957>

** Universidade da Integração Internacional da Lusofonia Afro-Brasileira (UNILAB), Redenção, CE, Brasil.silviana_mariz@unilab.edu.br <https://orcid.org/0000-0002-3561-2344>
} 
contexto de manutenção de desigualdades sociais e da subalternização dos povos indígenas e negros na contemporaneidade.

Palavras-chave: Revisionismo Histórico; Negacionismo; Mestiçagem; Negros; Indígenas. knowledge in a context of maintenance of social inequalities and the subalternization of indigenous and black people in contemporary times.

Keywords: Historical Revisionism; Negationism; Miscegenation; Blacks; Indigenous People.

Uma seita, minúscula, mas obstinada, dedica todos os seus esforços e emprega todos os meios, panfletos, fábulas, histórias em quadrinhos, estudos pretensamente científicos e críticos, revistas especializadas, para destruir, não a verdade, que é indestrutível, mas a tomada de consciência da verdade (Vidal-Naquet, 1988, p. 9).

As análises apresentadas por Vidal-Naquet permanecem indispensáveis para quem prima pelo ofício rigoroso da História. Trata-se de potente elaboração teórica que nos encaminha para reflexões densas sobre os riscos das fraudes contidas nos processos de revisionismo alavancados, geralmente, por pessoas não oriundas do campo dos Estudos Históricos, e que, não raro, desembocam em estudos negacionistas da própria História, baseados em ideologias de classe, raça e/ou gênero, mesmo que camufladas em discursos supostamente científicos.

É o que pode ser depreendido do livro O Cearense Revelado: uma jornada via DNA desvenda nossa ancestralidade (Santos, 2020). O anúncio de sua publicação, datado de 27 de julho de 2020, surpreendeu o Brasil devido à forma como a manchete a ele concernente foi disparada por um dos portais de notícias mais visitados no país. Sua chamada inicial, ainda preservada no endereço eletrônico do portal, informava: "cearenses têm maior influência genética de povos nórdicos do que de índios e negros, revela pesquisa" (Paulino, Torres, 2020a).

Passado o susto inicial, "o Ceará" e "os cearenses" conseguiram ocupar lugar de destaque entre as notícias mais comentadas nas redes sociais. Entre memes e piadas, a notícia continuou repercutindo nos portais de notícias, a exemplo do Terra e do $\mathrm{UOL}^{1}$, que foi um dos poucos a, desde a chamada da reportagem, convidar leitores à crítica em relação aos possíveis riscos implíci- 
tos em tal "achado" científico. O alvoroço publicitário, no final das contas, acabou por divulgar o livro, cuja autoria é de um docente do Departamento de Comunicação Social da Universidade Federal do Ceará (UFC), o jornalista Luís Sérgio Santos.

O Cearense Revelado tem como um de seus objetivos a divulgação daquilo que supostamente teria sido a "grande descoberta" da pesquisa científica conduzida por Eran Elhaik, geneticista e professor associado de bioinformática na Universidade de Sheffield, no Reino Unido. E qual seria essa "grande descoberta"? Em seu oitavo capítulo, de um total de 15, Santos se dedica a comentar os resultados da análise de seu colega de pesquisa que, em resumo - e conforme noticiado pelo jornal Diário do Nordeste -, atestariam que "nórdicos superam índios e negros na genética” (Paulino, Torres, 2020b) cearense. Contudo, o que essas reportagens não revelaram são os significados e as implicações profundas que pesquisas desta natureza carregam em si, muito menos os riscos e as atualizações por elas promovidas.

O presente artigo se propõe a refletir sobre os processos e os procedimentos de persistência e atualização de um dos negacionismos mais insistentes produzidos no Brasil, e que, no Ceará, é carregado de tintas e nuances bastante particulares, por vezes, produtoras de um discurso de mestiçagem responsável por menosprezar a participação indígena e africana na formação da população local. Em consonância com a narrativa romantizada e popularizada por José de Alencar em Iracema (1991 [1865]), ao Ceará tem sido imposta a fantasia de que "seu povo" teria sua origem ancestral embasada tão somente em matrizes indígenas e portuguesas. A partir da análise do livro O Cearense Revelado, mostramos como esse discurso de negação nunca foi completamente descartado no Ceará e, por extensão, no Brasil. Pelo contrário, a recente publicação traz atualizações ainda mais perigosas, porque travestidas de "ciência”, que reproduzem estigmas e ideologias.

\section{CiÊNCIAS E IDEOLOGIAS RACIAIS, ONTEM E HOJE}

O revestimento de ciência na produção de estudos em diferentes áreas não é algo recente. Trata-se de invólucro adotado desde, pelo menos, o século XIX, quando as teorias racialistas foram produzidas por sujeitos que reivindicavam o manto científico para revestir suas teses defensoras e propagadoras 
do ideal da supremacia racial branco-europeia. Tal perspectiva perdeu força a partir da derrota do nazismo na Segunda Guerra Mundial, contudo, apologistas da suposta superioridade do homem branco europeu, seja no campo genético ou cultural, voltam a ganhar voz através de diversos movimentos de extrema direita que emergiram nas últimas décadas em diversos países, abrindo margem para a repercussão e o consumo de "novos estudos" que requentam "velhas ideias" (Mbembe, 2014; Vidal-Naquet, 1988).

$\mathrm{Na}$ busca por validar tais narrativas, os revisionistas/negacionistas possuem regras próprias para sua produção, sendo "as técnicas mais evidentes: a mentira pura e simples, o falso, o apelo a uma documentação completamente fantástica" (Vidal-Naquet, 1988, p. 40) ou, ainda, a aplicação de "táticas sofisticadas de camuflagem" (Lipstadt, 2017, p. 34). E, assim, escondem suas intenções por trás da defesa de "revisar", "resgatar" e até mesmo "revelar" aquilo que uma suposta "historiografia corrompida" escondeu do grande público.

Nestes embates, jornalistas, políticos, empresários, enfim, pessoas que se autointitulam "estudiosos" e/ou "pesquisadores", interessados em explicar o mundo atual, têm recebido mais destaque, principalmente na internet, que a própria comunidade de historiadores. ${ }^{2}$ A onda conservadora e revisionista tem utilizado desde narrativas fantásticas divulgadas em redes sociais até métodos supostamente neutros, entre eles os estudos genéticos. Este é o caso de $O$ Cearense Revelado, obra baseada em "pesquisa com método biogeográfico GPS-DNA ORIGINS Ceará” e realizada "no laboratório DNA Diagnotics Center (DDC), em Fairfield, Ohio (EUA) a partir de amostras de saliva colhidas no universo Ceará" (Santos, 2020, pp. 89-90).

Sobre a reafirmação camuflada de hierarquias raciais e sociais a partir dos estudos genéticos, Mbembe alerta que "a lógica da raça volta, no entanto, a irromper na ciência contemporânea. Um pouco por todo o lado, volta a instaurar-se a fabricação de questões de raça", de modo que "longe de pôr fim ao racismo, um novo desdobramento da raça ancorou no pensamento do genoma. Ora pela exploração de origens genômicas das doenças em certos grupos, ora por genealogias das origens geográficas de indivíduos, o recurso genético tende a confirmar as tipologias raciais oitocentistas (branco caucasiano, negro africano, amarelo asiático)" (Mbembe, 2014, pp 44-45).

Seja para investigar doenças, seja para estabelecer origens biogeográficas de indivíduos, outro aspecto vaporizado nas pesquisas contemporâneas de 
mapeamento genético que emerge como potencialmente problemático é o de que tais estudos são desinteressados ou interessam-se, tão somente, no bem comum, possibilitando, finalmente, a certeza acerca das origens ancestrais das diferentes populações humanas. No lançamento de O Cearense Revelado, o pesquisador Eran Elhaik ressaltou que "o objetivo da pesquisa [...] é apenas rastrear a ancestralidade do cearense. Não é médica, não é forense, não é de nenhuma outra ordem" (Live de lançamento..., 2020).

Com isto, evidencia-se que, além de confirmarem as tipologias raciais do século XIX, os adeptos desta técnica a têm projetado como recurso científico imparcial e neutro. Todavia, suas conclusões acabam servindo à redução, ao apagamento ou à negação da importância, da experiência e da presença de povos historicamente marginalizados, articulando-se discursos e lógicas que excluem indígenas e afrodescendentes dos processos históricos. Tal manobra se encontra explicitada em O Cearense Revelado, cujo único capítulo reservado à África recebeu por título “África Ocidental, entreposto escravagista”, tornando a acionar antigas interpretações reducionistas do que o continente africano representou para a formação do Brasil.

Ao observarmos com mais vagar e profundidade este estudo, adepto do uso dos mapeamentos genéticos, percebemos que ele não apenas margeia o conhecimento histórico, mas dele se apropria, parcialmente, para a autolegitimação e a posterior adulteração. Por outro lado, há também o descuido e a usurpação do rigor metodológico com o trabalho de pesquisa e com a sua consequente teorização, durante o processo de interpretação das fontes históricas - que, não raro, sequer são acessadas.

\section{SOBRE A INVENÇÃO DO DESAPARECIMENTO DOS POVOS INDÍGENAS NO CEARÁ}

Os discursos que apontam para o desaparecimento dos povos indígenas no Ceará tornaram-se hegemônicos desde a década de 1860, merecendo destaque a publicação do romance Iracema, de José de Alencar (1991). Nesta obra, em que a gênese do cearense é representada na personagem de Moacir - filho legítimo de Martim Soares Moreno, conquistador português, com a indígena tabajara Iracema -, a origem do "povo cearense" ocorre mediante a morte da tabajara que representa, simbolicamente, o desaparecimento dos povos indígenas. 
Essa formulação, “confirmada” por outras narrativas, pavimentou o terreno no qual a ideologia do desaparecimento dos povos indígenas, no Ceará, estabeleceu-se como fato, e, até mesmo, como verdade histórica, reverberando, hoje, nas pesquisas baseadas na genética, que anunciam, como "grande surpresa", a diminuta importância das matrizes indígenas em nossa composição étnica. Pesquisas como a que resultou em $O$ Cearense Revelado tanto conduzem quanto chancelam o equivocado senso comum de que as populações indígenas desapareceram durante o processo de colonização. No entanto, elas remontam diretamente ao relatório de governo do então presidente do Ceará, José Bento da Cunha Figueiredo Júnior, apresentado à Assembleia Provincial em 1863.

Possivelmente em decorrência da solenidade da ocasião, o feito, que consistia na mera leitura do relatório, ganhou peso de aprovação de decreto, tendo obtido notoriedade como o "Decreto de Extinção" (Silva, 2011a), que oficializava o suposto desaparecimento das populações indígenas localmente. Nele, o presidente de província assevera: “Já não existem aqui índios aldeados ou bravios. Das antigas tribos de Tabajaras, Cariris e Potiguaris, que habitavam a província, uma parte foi destruída, outra emigrou e o resto constituiu os aldeamentos da Serra da Ibiapaba [...]. Andam-se hoje misturados na massa geral da população" (Cunha Figueiredo Junior, 1863, pp 19-20).

Este episódio não foi isolado e transbordou em vários outros esforços de afirmação do desaparecimento dos povos indígenas no Ceará. É possível interpretarmos a leitura do relatório - e a sua respectiva elevação à condição de decreto - como uma ação política de manipulação da história e como "uma tentativa de extermínio no papel, que substitui o extermínio no real” (Vidal-Naquet, 1988, p. 45). Tal ação leva ao que Baéz chamou de "memoricídio", que consiste no extermínio das memórias ligadas a um povo (Baéz, 2010, p. 288), constituindo ato fundacional do negacionismo que justificaria a ausência e/ou a limitação de políticas públicas para as populações indígenas locais desde o século XIX.

É preciso lembrar, entretanto, que o apagamento ou o avivamento de memórias, por vezes, também pode implicar na definição do lugar, social e político, que o Estado reserva aos grupos sociais de uma sociedade (Pollak, 1989, p. 9). Ou seja, a construção - e por decreto -, na memória coletiva dos cearenses, da extinção indígena, implica, simultaneamente, na condição de 
subalternidade e invisibilidade reservada aos povos indígenas no Ceará, através da fabricação de vazios narrativos e de lugares amnésicos, pela ausência de comemorações e de referências (Michel, 2010, p. 20).

Por outro lado, é preciso assinalar que os discursos do poder público, durante muito tempo, encontraram acolhida nas narrativas pretensamente científicas de instituições como os Institutos Históricos, fundados no Brasil ao longo do século XIX. No caso do Ceará, apesar de não terem sido escritas por historiadores propriamente ditos, várias obras cujas produções estiveram sob o incentivo e a tutela do Instituto Histórico, Geográfico e Antropológico do Ceará (ou simplesmente Instituto do Ceará, IC) 3 foram responsáveis por legitimar a alquimia que possibilitou que a simples leitura de um relatório provincial se tornasse um "decreto de extinção" (Silva, 2011a).

Entre as obras que reverberam as visões do IC, destaca-se $O$ Cearense (Barroso, 2017 [1969]), de autoria do ex-governador e ex-deputado federal pelo Ceará Parsifal Barroso, diretamente implicado na publicação do recente O Cearense Revelado, cujo idealizador e prefaciador é o seu neto, o empresário cearense Igor Queiroz Barroso. Igor Barroso atua como um aspirante a mecenas da cultura cearense, supostamente desinteressado. Todavia, carrega consigo os sobrenomes de duas famílias poderosas no Ceará: pelo ramo paterno, a família Barroso; pelo materno, seu avô é Edson Queiroz e sua mãe, Myra Eliane Queiroz Barroso, uma das herdeiras do Grupo Edson Queiroz ${ }^{4}$, detentor de uma das maiores fortunas do Ceará.

Para patrocinar suas atividades filantrópicas, Igor Barroso dirige uma fundação homenageando sua mãe, denominada Fundação Myra Eliane, instituição que possibilitou ao empresário tomar para si a missão de continuar a obra do avô paterno, ao decidir financiar a pesquisa que deu origem à publicação de O Cearense Revelado - obra que contou, ainda, com o "apoio cultural” da FIEC, Federação de Indústrias do Estado do Ceará.

Assim, no lastro de seu contexto de produção e dos vínculos familiares e empresariais de seu principal financiador, O Cearense Revelado é uma obra de marketing exemplar de como os estudos genéticos podem ser deturpados e manipulados para justificar narrativas que revisitam e recompõem velhos estigmas. Deste modo, o livro entrelaça passado e presente como se fossem pontas soltas e apenas estivessem aguardando para serem novamente atados. Os esforços empreendidos para que a publicação viesse à tona representam a 
"perspectiva de uma única geração histórica”, segundo a qual "presente e passado estariam, assim, circundados por um horizonte histórico comum” (Koselleck, 2007, p. 22).

No livro, desenvolvido ao longo de três partes ${ }^{5}$, cujo enredo apresenta desde as motivações de sua publicação até os perfis comentados de alguns dos participantes da pesquisa, ora identificados como "personagens", ora como "amostras", pouco espaço é dedicado aos povos indígenas. Dos seis capítulos que abordam, especificamente, os principais bolsões genéticos que supostamente compõem o "povo cearense", apenas um é, de algum modo, dedicado às origens dos povos indígenas. Intitulado "América Central, conexão norte-sul”, este capítulo ocupa apenas 11 das 352 páginas do livro. O mais problemático, entretanto, não é sequer a quantidade, mas a qualidade do conteúdo; a forma como são analisados os dados e as obras adotadas como referencial historiográfico.

Neste rumo metodológico, o autor segue primando em simplesmente reproduzir elaborações como as do engenheiro e membro do Instituto do Ceará Pompeu Sobrinho, que, ao exaltar a miscigenação, retratava os povos indígenas como meros figurantes de um cenário histórico cujo protagonismo teria sido desempenhado exclusivamente pelos portugueses. Ao repetir, sem nenhuma problematização, que "esta gente, homens sem mulheres da sua estirpe, ao pisar a terra logo entrava em relações sexuais com as índias que lhe não opunham a menor resistência, seduzidas pelo aspecto singular, mas atraente e a riqueza esquiva que ostentava" (Santos, 2020, p. 194), Santos atualiza mitos e estereotipias que subalternizam os povos indígenas no Ceará.

Chamamos a atenção para a quantidade de páginas porque acreditamos que, em seu conjunto, elas revelam mais do que números. Ao analisar os bolsões genéticos europeus, Santos lhes reserva três capítulos: um, bastante compreensível e esperado, tratando dos povos ibéricos; outro, abordando a influência dos franceses na constituição do cearense; e um terceiro, contemplando especificamente os povos vikings, que, diga-se de passagem, é o capítulo que mais acumula páginas em relação aos demais, incluindo aqueles dedicados aos povos indígenas e africanos. Vejamos: enquanto os capítulos "País basco, o sangue ferve" e "Sul da França, francês cearense" reúnem respectivamente dez e cinco páginas, "Fennoscandia e a Era Viking", sozinho, soma quase 17 páginas. No total, aos bolsões genéticos europeus são dedicadas um total de 32 páginas. E 
quanto aos capítulos sobre os bolsões indígenas e africanos? Os dois, somados, representam menos da metade do que foi dedicado aos povos da Europa, ou seja, 15 páginas: “África Ocidental, entreposto escravagista” e "América Central, conexão norte-sul" totalizam, respectivamente, quatro e onze páginas ${ }^{6}$.

Outro aspecto que consideramos problemático é a ordenação desses capítulos, sendo "Fennoscandia e a Era Viking" o primeiro na sequência. Tal ordenamento, da mesma forma que a quantidade de páginas de cada capítulo, não nos parece inocente coincidência ou ato falho despropositado. Ao contrário, entendemos todos esses elementos como compondo a mensagem final que o autor tanto quer construir: a de que, no Ceará, mais importantes foram os eixos étnicos franco-escandinavos que, a partir de sua diáspora na Ibéria, teriam migrado em grandes números populacionais masculinos para a América e aqui constituíram populações com "furor e sêmen" (Santos, 2020, p. 172).

O mais problemático, portanto, não é apenas o que Santos afirma, mas, antes, o quanto e como afirma. Não sendo suficientes os silêncios e as lacunas sobre os povos indígenas, cuja história emerge de modo reduzido, Santos ainda manipula a exposição de dados genéticos para evidenciar o protagonismo dos povos europeus. Abrindo o capítulo "Fennoscandia e a Era Viking”, Santos afirma:

O genoma Fennoscandia (456,4\%) rivaliza com o genoma América Central (424,9\%) no DNA do cearense, evidenciando a fusão genética entre o "branco-europeu" e o "ameríndio". Essa predominância "branca" se amplia quando outros bolsões genéticos convergentes são agrupados, como mostra a análise feita pelo geneticista Eran Elhaik (Santos, 2020, p. 163).

Os “outros bolsões genéticos convergentes" correspondem exatamente aos ibéricos e aos franceses, que foram convenientemente acionados para comprovar a tese já firmada previamente de que os cearenses seriam mais europeus do que afroindígenas. Como bom comunicador que é, Santos sabe bem que uma afirmação repetida insistentemente ganha ares de verdade, e assim o faz inúmeras vezes ao longo do livro. Dito isto, não é que ele negue tacitamente a participação de indígenas e africanos - tanto que ele reserva capítulos para esses dois povos. O problema repousa na forma diminuta, estereotipada e passageira de sua abordagem.

Por outro lado, uma presença permanente e repetida é a dos bolsões ge- 
néticos europeus, em especial os da Fennoscandia. Para Santos, "Algo que traduz a fortaleza desse bolsão genético é a palavra 'viking'. [...]. Suas assinaturas genéticas, espalhadas pela Europa em anos de dominação, colonização e barbárie, estão no DNA dos cearenses." (Santos, 2020, p. 165). Ao leitor otimista, tal passagem talvez acabe por chamar atenção pela presença das palavras "dominação", "colonização" e "barbárie". Contudo, quem segue adiante na leitura acaba por descobrir que o uso de tais palavras não se destina a produzir uma reflexão crítica sobre os processos históricos narrados; ao contrário, elas são usadas para comunicar a pretensa grandeza e superioridade dos vikings.

\section{OBRAS DISTINTAS E UM MESMO HORIZONTE DE EXPECTATIVAS?! NEGANDO A IMPORTÂNCIA DE NEGROS E NEGRAS NA COMPOSIÇÃO DO POVO CEARENSE}

O Cearense Revelado também repercute o apagamento da presença negra na composição étnica cearense, ao enfatizar a suposta prevalência do grupo genético da Fennoscandia, com recorrência "tão intensa e tão disseminada que aparece em amostras de 'índios', 'quilombolas', 'brancos', 'negros' e 'pardos'.” (Santos, 2020, p. 164).

A partir de 160 amostras de DNA coletadas no Ceará, identificou-se 27 "bolsões genéticos" com origens localizadas geograficamente, sendo os dez mais dominantes: $1^{\text {a }}$ Fennoscandia (Escandinávia); $2^{\circ}$ América Central; $3^{\circ} \mathrm{Sul}$ da França; 4 País Basco; 5 Sardenha; 6 Ilhas Órcades (Norte da Escócia); 7º Sibéria Ocidental; $8^{\circ}$ Tuva (Centro-Sul da Rússia); $9^{\circ}$ Sudeste da Índia; e $10^{\circ}$ Noroeste da África (Santos, 2020, pp. 91-92).

Com base nesses dados, os conjuntos genéticos europeus superam os bolsões genéticos ameríndios e africanos, apesar de, isoladamente, o bolsão genético ameríndio "América Central" quase rivalizar com o europeu "Fennoscandia”. O primeiro bolsão genético oriundo da África só apareceu na $10^{\text {a }}$ colocação, teia que levou à afirmação: "os genomas de assinatura africana são percentualmente de pequena quantidade no universo do Ceará. Isso cristaliza o registro histórico de que (...) o Estado sempre abrigou uma pequena quantidade de negros" (Santos, 2020, p. 94, grifo nosso).

Aí, ocorre outra manipulação na pesquisa, já que o autor não relaciona a suposta herança genética com o contexto histórico da formação étnico-racial 
cearense, desconsiderando as migrações compulsórias ou "voluntárias" e as diversas comunidades de cearenses espalhadas pelo Brasil, de Benevides no Pará às favelas do eixo Centro-Sul do país (Barboza, 2013; Morais, 2003). Aliás, a amostragem é reduzida. Considerando-se uma população superior a nove milhões de habitantes ${ }^{7}$, foram coletadas apenas 160 amostras de DNA, não se apresentando nenhum rigor estatístico na seleção. Proporções e critérios geracionais, de renda ou autoidentificação racial foram simplesmente ignorados.

A impressão deixada pelo livro é a de que o DNA foi coletado entre circuitos próximos ao financiador e ao autor da obra, ou seja, a pesquisa contou, sobretudo, com a participação do ex-governador e de empresários, advogados, professores universitários, enfim, de figuras ligadas à elite econômica ou intelectual cearense. A inclusão de uma liderança indígena, de um morador de uma comunidade afrodescendente e de raras pessoas autoidentificadas como negras parece se configurar muito mais como uma prática evidente de tokenismo ${ }^{8}$ do que como genuína representatividade (Jennings, 2004). Ainda questionamos: por que áreas periféricas de Fortaleza ${ }^{9}$, tais como a Grande Barra do Ceará ou o Bom Jardim, apesar de concentrarem as maiores densidades populacionais da capital cearense, não estão representadas nas amostras de DNA utilizadas na pesquisa? A metodologia de análise, voltada à testagem de uma pequena quantidade de sujeitos, nos fornece mais perguntas do que nos atesta a acuidade do processo de investigação que originou o livro. Considerando-se o contexto em que o material foi produzido, supomos que houve manipulação de dados tendo como objetivo a comprovação de uma dupla tese já pré-definida: a de que há, por um lado, a prevalência de um "Ceará Viking”, e, por outro, a redução da importância de indígenas e negros na composição da população cearense.

Assim, a obra sorrateiramente apaga e reatualiza o discurso de assimilação e desaparecimento dos grupos étnicos indígenas, conforme destacado anteriormente; e, também, de africanos, ao trazer para o século XXI a mesma lógica narrativa de estudos oitocentistas cuja tônica foi a negação ou a redução da presença negra na formação do Ceará, produzindo, assim, uma antimemória dessas matrizes étnicas. Segundo Mbembe, o projeto de apagamento e a consequente negação da participação das populações afroindígenas é um processo comum em toda a América, especialmente no Sul, onde "as novas elites se apropriam da ideologia da mestiçagem para negar e desvalorizar a questão 
racial. A contribuição dos Afro-Latinos e dos escravos negros para o desenvolvimento histórico da América do Sul será apagada ou [...] severamente ocultada." (Mbembe, 2014, p. 35).

Vários foram os articulistas da Revista do Instituto do Ceará (RIC) que incorreram nesse procedimento narrativo. Ao analisar o debate sobre a mestiçagem, a partir de um artigo da primeira edição da RIC, publicada em 1887, observa-se que "Paulino Nogueira descartou a mestiçagem entre índios e negros no Ceará, reafirmando uma tese recorrente entre outros historiadores do Instituto do Ceará, qual seja, a particularidade local no que se refere ao fato de a mestiçagem ser restrita a brancos e índios” (Oliveira, 2001, p. 119).

Nos anos 1960, a retórica oitocentista ainda permanecia em destaque. Instigado por Gilberto Freyre, Parsifal Barroso ${ }^{10}$, na obra O Cearense, de 1969 - período de acomodação dos primeiros governos de ditadura militar no país -, aborda a constituição étnica do povo do Ceará, ao mesmo tempo em que reproduz uma série de estigmas ou equívocos, retomando, inclusive, um debate voltado a revisar "o mito das três raças", atualizando, excluindo e substituindo uma delas:

Como não há dúvida quanto à impossibilidade de se ter no Ceará a presença ponderável do elemento africano, surgiram opiniões favoráveis à aceitação de uma etnia que o substituísse [...] o ilustre historiador Antonio Bezerra sempre considerou possível a terceira etnia em nossa formação. Refiro-me à miscigenação cigana, de aceitação generalizada (Barroso, 2017, p. 41).

Parsifal Barroso, apesar de utilizar linguagem erudita, produziu uma obra repleta de equívocos, e mesmo o que poderia ser destacado como contribuição mais relevante, o papel dos ciganos na composição da população do Ceará, nada mais é do que a reprodução de uma argumentação apresentada anteriormente por Antônio Bezerra, membro da primeira geração do Instituto do Ceará, que, em 1906, publicou O Ceará e os Cearenses, considerada uma das primeiras descrições locais do "mito das três raças": portugueses, indígenas e ciganos.

Importa destacar que a inclusão dos ciganos na formação étnica dos cearenses ocorreu porque Bezerra, na verdade, buscava explicar as causas da constante emigração de cearenses, embora as suas hipóteses não considerassem a concentração de terras produtivas e das reservas de água ou a desestruturação 
da agricultura de subsistência pela agricultura comercial, especialmente do algodão, como eventos que fragilizaram a vida do roceiro cearense, estando, portanto, na base de qualquer análise mais complexa sobre as diversas razões da migração de cearenses.

Ao contrário, Bezerra opera a partir do universo intelectual comum à passagem do século XIX ao XX, em que as teorias racialistas eram hegemônicas nos circuitos letrados, fazendo com que a explicação para a constante migração fosse baseada em fatores atávicos, como aquele que dizia estar no "sangue cearense" o motivo do fenômeno, herdado pelo amor à liberdade, comum aos indígenas e aos ciganos: "si os nossos patrícios não têm sangue cigano, não há coisa mais parecida. Um homem do Ceará é um cigano”. Bezerra ainda segue argumentando que uma "Ordem Régia de 15 de abril de 1718 mandou remeter para o Ceará e para Angola os ciganos degredados do Reino, e parece que por aqui se deram bem" (Bezerra, 1906, p. 15). Desconsiderando os conflitos sociais, a argumentação da ascendência do "sangue cigano" resolveria a equação explicativa para as causas da emigração cearense.

Sem desprezar a inusitada hipótese da participação cigana como marcador da composição étnica cearense, a introdução de escravizados negros, no Ceará, durou muito mais tempo que uma ordem pontual de deportação e foi muito maior em quantidade, já que ocorreu desde as décadas iniciais do século XVIII até, pelo menos, a década de 1830. Ainda assim, os negros acabaram substituídos pelos ciganos na narrativa de Antônio Bezerra, o que constitui um malabarismo argumentativo e tanto.

Além disso, embora a escravidão não tenha desempenhado papel preponderante, no Ceará, quando comparado a outras capitanias, em 1819, por exemplo, dentre os 201.170 habitantes cearenses, “55.239 eram escravos, representando $28 \%$ de todos seus habitantes” (Silva, 2011b, p. 74). Pode-se argumentar que, desde 1850, muitos dos escravizados cearenses foram negociados para o Tráfico Interprovincial, e com mais intensidade a partir da grande seca de 1877, o que acabou reduzindo a presença de escravizados na economia. Porém, o raciocínio não pode desprezar as alforrias constantes, o que possibilitava a permanência, no Estado, de negros e negras na condição de libertos, sem contar aqueles que já chegavam ao Ceará na condição de livres atraídos pela pecuária: 
Nos sertões da Bahia, Pernambuco e Ceará, diz ele [...] abundam mulatos, mestiços e pretos forros (devia acrescentar índios mais ou menos mansos). Esta gente perversa, ociosa e inútil pela aversão ao trabalho na agricultura, é muito diferentemente empregada nas fazendas de gado (Abreu, 1988, p. 140).

Apesar da existência dos indícios apontando a relevância de negros livres ou escravizados na composição da população cearense, Antônio Bezerra e Parsifal Barroso preferiram ignorar e negar tal relevância, substituindo-a pela valorização do "sangue cigano". Que Antônio Bezerra tenha construído esta formulação é compreensível, afinal, ela estava em sintonia com o pensamento social racista da chamada Belle Époque; porém, Parsifal Barroso não merece a mesma condescendência, afinal, em 1969, as teorias raciais já estavam em declínio desde a derrota do Nazismo. Além disso, a ascensão dos movimentos de descolonização da África e a popularização da antropologia cultural permitiam analisar a cultura negra e africana e as composições étnicas segundo outros parâmetros. No entanto, Barroso preferiu simplesmente reproduzir a abordagem de Bezerra.

De maior impacto é a atualização financiada pelo neto de Parsifal Barroso, pois, se, no livro do ex-governador, são os ciganos que tomam o lugar da presença negra no Ceará, em O Cearense Revelado são os vikings! É preciso perceber o jogo político destes “empreendedores de memória” (Michel, 2010): tanto ciganos quanto nórdicos representaram minorias inegáveis no Ceará! $\mathrm{E}$ seus autores sabiam disso ${ }^{11}$ ! No entanto, a publicidade, por eles produzida, em torno dessas ideias, acabou garantindo curiosidade e visibilidade.

Em O Cearense Revelado, Santos dispensa tão somente quatro páginas para discorrer sobre a África Ocidental e a sua importância na constituição étnico-racial brasileira e cearense. Apesar de descrever a África como "uma terra de cidades-estado e de inovação tecnológica” (Santos, 2020, p. 181), a narrativa segue aos saltos por diferentes temporalidades, sem, no entanto, detalhar a sua relevância, conforme foi feito em relação aos povos europeus descritos. A África aparece vinculada fortemente ao tráfico de escravos, sendo, desde o título do capítulo, descrita como um "entreposto escravagista" (Santos, 2020, p. 181).

No capítulo "Os Grupos Genéticos do Cearense”, que antecede os demais abordando cada bolsão genético, Santos apresenta sumariamente os grupos étnicos que ele considera mais importantes. Antecipando interpretações e vi- 
sões de modo profundamente acrítico sobre cada um desses grupos, seus locais de origem e, principalmente, os processos de mestiçagem que sofreram, o autor argumenta existir, como produto final da experiência colonial, a herança de "propriedades" ou características civilizatórias da classe senhorial. Noutras palavras, trata-se da teoria do branqueamento racial revisitada:

O Brasil foi o grande caldeirão de miscigenação, uma curra selvagem e desembestada, uma relação de poder de força e de encantamento do colonizador sobre o colonizado. Primeiro o europeu sobre o ameríndio e, depois, os senhores de engenho sobre as negras africanas. As relações eram de força física e de compra de sexo tanto que as negras escravas tinham maior cotação nos balcões de compra e venda. [...] Gradativamente, iniciou-se um processo civilizatório onde a força abria frestas para o afeto, onde descendentes de conjunções meramente carnais começavam a herdar propriedades dos seus senhores pais (Santos, 2020, p. 145).

Por fim, no epílogo "O Padrão é a Mistura”, Santos afirma que "Com um cotonete (swab) na bochecha, uma coleta de saliva e um preço em queda no balcão das farmácias Walgreens qualquer pessoa pode ter acesso a uma pesquisa sobre sua ancestralidade" (Santos, 2020, p. 268), apresentando, com isto, uma visão reducionista do que seja ancestralidade, ao levar em consideração tão somente os aspectos biológicos, menosprezando o peso da cultura na formação de nossas ancestralidades.

\section{Conclusẽo}

Como apontam Patrícia Valim e Alexandre de Sá Avelar, o termo negacionismo ganhou relevo no contexto "do pós-guerra quando alguns indivíduos alcançaram popularidade ao postularem que o extermínio dos judeus havia sido uma gigantesca farsa histórica patrocinada por poderosos interesses políticos.”. A partir daí, os seus adeptos, agora chamados de negacionistas,

procuraram legitimar seus lugares no campo intelectual ao afirmarem que suas teses falaciosas eram 'revisionismos históricos', elaborados por meio dos procedimentos metodológicos obrigatórios do trabalho do historiador: levantamento e exame crítico das fontes, construção de hipóteses explicativas e formulação de conclusões objetivas. Ao estabelecerem indevidas relações de equivalência entre as teses negacionistas e o legítimo exercício de revisão historiográfica, alguns se- 
tores da imprensa, da política e da comunidade acadêmica da França naturalizaram formas de falsificação do passado (Valim; Avelar, 2020).

Deste modo, o negacionismo ultrapassou a abordagem inicial de negar somente o Holocausto, sendo, atualmente, utilizado como instrumento de governabilidade pela extrema-direita, para viabilizar políticas ultraliberais de eliminação de direitos.

No Brasil, enfrentamos, entre outros, o negacionismo da ditadura civil-miliar iniciada em 1964, ou da existência da tortura, como forma de se reconstruir a imagem dos militares encastelados no Palácio do Planalto. Há ainda os discursos da inexistência do racismo no país ou as falácias de que a escravidão teria trazido benefícios para os negros. Enfim, versões atualizadas das negações mais absurdas produzidas anteriormente; afinal, não se pode ignorar que muitos dos negacionismos atuais são, na verdade, recuperação de negações proferidas em nosso passado. Como esquecer, por exemplo, que Gilberto Freyre, além de ter subsidiado a defesa de uma suposta democracia racial no Brasil, fazia questão de usar o termo "movimento de 31 de março" (Freyre, 1983, p. 13), ao invés de golpe, para se referir ao assalto ao poder realizado pelos militares no Brasil em 1964?!

Infelizmente, tais negações, hoje, encontram, na modernidade virtual, formas de serem potencializadas e, assim, turbinadas; multiplicando-se tanto através de blogs e vídeos de Youtubers de direita compartilhados na internet, quanto de recursos espalhafatosos de propaganda disfarçados de ciência. É neste cenário que se insere o livro O Cearense Revelado, cuja metodologia, ao ter manipulado dados genéticos de modo nebuloso, ultrapassou o limite do simples revisionismo, tendo, com isso, se inscrito também entre as obras permeadas pelo negacionismo histórico.

Por esta razão, portanto, entendemos que qualquer estudo com a pretensão de abordar a composição do "povo cearense" não pode considerar somente a coleta do DNA de amostras minúsculas de sua população. É impossível não se levar em conta as condições históricas e culturais desde a colonização, bem como a formação social do Ceará e de seus povos e as injunções econômicas, marcadas pela alta concentração de terras promovida pela pecuária e pelo avanço da agricultura comercial contra as terras de indígenas, roceiros, negros livres e pobres em geral. Todo esse cenário, uma vez somado aos períodos de secas, influenciaram intensos movimentos migratórios desde o fim do 
século XIX, fazendo com que parte considerável do DNA “indígena” e "negro" cearense tenha sido exportada para os seringais e as cidades da Amazônia (Barboza, 2013) e/ou para os cafezais, as indústrias e os serviços de São Paulo, Rio de Janeiro e outras áreas de expansão econômica (Morais, 2003).

Além de todas as críticas possíveis em relação à ausência de método na seleção e na interpretação das fontes, bem como de diálogo com perspectivas teóricas atualizadas no campo dos estudos históricos e antropológicos, a pesquisa que fundamentou $O$ Cearense Revelado explorou o DNA de somente 160 pessoas, sem revelar como ocorreu o processo de coleta ou explicar os critérios de seleção e tamanho das amostras por segmentos de classe, de sexo, de idade/ geração e de raça/cor. No referido livro, somente no capítulo 15 é que o autor apresenta quem foram "suas fontes".

O capítulo intitulado "A Fala de Algumas Amostras", único que compõe a "Parte 3 - Personagens, Campo, Pedaços da Memória e DNA", expõe algumas informações de apenas 19 indivíduos ${ }^{12}$ que participaram da pesquisa. Entre eles, somente uma coleta ocorreu no povo indígena Jenipapo-Kanindé, localizado em Aquiraz, cidade próxima à Fortaleza, capital do Ceará, apresentando, juntamente com outras três amostras, genes predominantes ameríndios; somente uma amostra foi coletada na comunidade negra dos Caetanos, do município de Beberibe ${ }^{13}$, perfil que indicou prevalência de $37 \%$ de genes africanos; uma segunda amostra, coletada em Fortaleza, também indicou prevalência genética africana; uma amostra, coletada com um homem de origem libanesa, apresentou prevalência genética do Sudeste da Índia; e, das demais 12 amostras identificadas, em todas prevaleciam os "genes europeus" (Fennoscandia, Sul da França e Sardenha), sendo coletadas entre advogados, jornalistas e políticos, a exemplo de Gonzaga Mota, ex-governador do Ceará (Santos, 2020, pp. 225-266).

Portanto, ao final da leitura, ainda questionamos: e as outras 141 amostras não detalhadas, foram coletadas onde e com quem? Entre a elite empresarial de Fortaleza, grupo no qual o financiador da pesquisa está inserido? A quem interessa o discurso comprometido em reduzir a presença indígena e negra no pretérito e deslegitimar suas lutas por retomada de terras no presente? Parafraseando um famoso historiador inglês, podemos dizer que o DNA não revela seu próprio significado, precisa ser interrogado ${ }^{14}$; pois, assim como outros 
vestígios da ação do homem no tempo, não podemos deixar de fazer perguntas às fontes e interpretá-las com base em referenciais teóricos consistentes.

Contudo, a despeito de narrativas negacionistas, úteis à colonialidade de poderes e saberes (Lander, 2005), atualmente, o Estado do Ceará possui mais de 14 povos indígenas, distribuídos em 18 municípios diferentes (Rodrigues, 2019), além de 52 comunidades remanescentes de quilombos, certificadas pela Fundação Palmares e distribuídas em 29 municípios cearenses (Fundação Palmares, 2020). São grupos que resistiram e continuam a resistir contra iniciativas passadas e presentes que buscam silenciar suas existências e reconhecimento de direitos.

Dito isto, finalizamos o presente artigo lembrando, conforme recomenda Vidal-Naquet, que "cabe aos historiadores arrancarem os fatos históricos das mãos dos ideólogos que os exploram” (Vidal-Naquet, 1988, p. 34). Acreditamos ser este, hoje, um dos nossos principais combates.

\section{REFERÊNCIAS}

ABREU, Capistrano de. Caminhos Antigos e Povoamento do Brasil. Belo Horizonte: Itatiaia; São Paulo: EDUSP, 1988.

ALENCAR, José de. Iracema. 24a Ed. São Paulo: Ática, 1991 [1865].

ANPUH-BRASIL. Disponível em: https://www.youtube.com/channel/UCYwepnQFduxOovsCrJEx32g. Acesso em: 14 mar. 2021.

BAÉZ, Fernando. A história da destruição cultural da América Latina: da conquista à globalização. Rio de Janeiro: Nova Fronteira, 2010.

BARBOZA, Edson Holanda Lima. A hidra cearense: rotas de retirantes e escravizados entre o Ceará e as fronteiras do Norte (1877-1884). Tese (Doutorado em História Social) - Programa de Pós-Graduação em História, Pontifícia Universidade Católica de São Paulo. São Paulo, 2013. 255f.

BARROSO, Parsifal. O Cearense. $2^{a}$ Ed. São Paulo: Escrituras Editora; Instituto Myra Eliane, 2017 [1969].

BEZERRA, Antônio. O Ceará e os Cearenses. Fortaleza: Editora-Assis Bezerra, 1906.

BRASIL PARALELO. Disponível em: https://www.youtube.com/channel/UCKDjjeeBmdaiicey2nImISw. Acesso em: 14 mar. 2021.

CUNHA FIGUEIREDO JUNIOR, José Bento da. Relatorio apresentado á Assembléa Legislativa Provincial do Ceará pelo excellentissimo senhor dr. José Bento da Cunha Figueiredo Junior. 9 out. 1863. Disponível em: http://ddsnext.crl.edu/

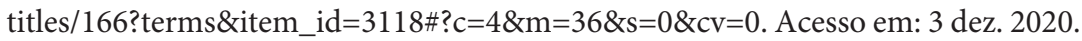


FALCÃO, Marina. Em nova fase, grupo Edson Queiroz investe em usina eólica e construção. 10 dez. 2018. Disponível em: https://valor.globo.com/empresas/noticia/2018/12/10/em-nova-fase-grupo-edson-queiroz-investe-em-usina-eolica-e-construcao.ghtml. Acesso em: 1 dez. 2020.

FORTALEZA 2040: PUBLICAÇÕES. Disponível em: https://fortaleza2040.fortaleza. ce.gov.br/site/fortaleza-2040/publicacoes-do-projeto. Acesso em: 12 mar. 2021.

FREYRE, Gilberto. A propósito do cearense: sugestões em torno de sua etnia e do seu "ethos". Revista da Academia Cearense de Letras, Fortaleza: ACL, v. 3, pp. 11-25, 1983.

FREYRE, Gilberto. Precisa-se do Ceará. O Jornal, Rio de Janeiro, 9 set. 1944, p. 4. Disponível em: http://memoria.bn.br/DocReader/docreader.aspx?bib= 110523_04\&pasta=ano\%20194\&pesq=Gilberto\%20Freyre\&pagfis=23390. Acesso em: 1 dez. 2020

FUNDAÇÃO PALMARES: Tabela completa CRQ. 29 out. 2020. Disponível em: http:// www.palmares.gov.br/sites/mapa/crqs-estados/crqs-ce-29102020.pdf. Acesso em: 2 dez. 2020.

JENNINGS, James. Tokenism. In: CASHMORE, Ellis (Org.). Encyclopedia of race and ethnic studies. London; New York: Routledge, 2004.

KOSELLECK, Reinhart. Futuro Passado: contribuição à semântica dos tempos históricos. Rio de Janeiro: Contraponto; Ed. PUC-Rio, 2007.

LANDER, Edgardo (Org.). A colonialidade do saber: Eurocentrismo e ciências sociais. Perspectivas latino-americanas. Buenos Aires: CLACSO, 2005.

LIPSTADT, Deborah E. Negação. Tradução de Mauricio Tamboni. São Paulo: Universo dos Livros, 2017.

LIVE DE LANÇAMENTO do livro "O Cearense Revelado". 5 ago. 2020 (48 min. 47 seg.); son.; color. Disponível em: https://www.youtube.com/watch?v=EB3hRY bE86w. Acesso em: 12 nov. 2020.

MBEMBE, Achille. Crítica da Razão Negra. Lisboa: Antígona, 2014.

MICHEL, Johann. Podemos falar de uma política do esquecimento? Revista Memória em Rede, Pelotas: Programa de Pós-Graduação em Memória Social e Patrimônio Cultural; UFPel, v. 2, n. 3, pp. 14-26, 2010.

MORAIS, Viviane Lima de. Razões e destinos da migração: trabalhadores e emigrantes cearenses pelo Brasil no final do século XIX. Dissertação (Mestrado em História Social) - Programa de Pós-Graduação em História, Pontifícia Universidade Católica de São Paulo. São Paulo, 2003. 225f.

OLIVEIRA, Almir Leal de. O Instituto Histórico, Geográfico e Antropológico do Ceará: memória, representações e pensamento social (1887-1914). Tese (Doutorado em História Social) - Programa de Pós-Graduação em História, Pontifícia Universidade Católica de São Paulo. São Paulo, 2001. 280f. 
ORIGEM DO POVO cearense é mapeada a partir do DNA e publicada em livro. 7 ago. 2020. Disponível em: https://www.terra.com.br/noticias/dino/origem-do-povocearense-e-mapeada-a-partir-do-dna-e-publicada-em-livro,8504995de56c85f725 47140ca15cabcejjcknabq.html. Acesso em: 1 dez. 2020.

PÁDUA MARTINS. Pesquisa revela que dos 9,1 milhões de habitantes no Ceará, 77,4\% estão em áreas urbanas e 22,6\% em áreas rurais. 29 jan. 2021. Disponível em: https://www.ceara.gov.br/2021/01/29/pesquisa-revela-que-dos-91-milhoes-de-habitantes-no-ceara-774-estao-em-areas-urbanas-e-635-da-populacao-tem-idade-ativa/. Acesso em: 13. mar. 2021.

PAULINO, Nícolas; TORRES, Alessandro. Cearenses têm influência genética de povos nórdicos, revela pesquisa. 27 jul. 2020a. Disponível em: https://g1.globo.com/ce/ ceara/noticia/2020/07/27/cearenses-tem-maior-influencia-genetica-de-povos-nordicos-do-que-de-indios-e-negros-revela-pesquisa.ghtml. Acesso em: $1 \mathrm{dez}$. 2020.

PAULINO, Nícolas; TORRES, Alessandro. Origem do cearense: nórdicos superam índios e negros na genética. 27 jul. 2020b. Disponível em: https://diariodonordeste. verdesmares.com.br/metro/origem-do-cearense-nordicos-superam-indios-e-negros-na-genetica-1.2970540. Acesso em: 1 dez. 2020.

PHILIPPE, Pedro. Apagou negros e índios: estudo irrita cientistas ao ligar cearense a viking. 11 ago. 2020. Disponível em: https://www.uol.com.br/tilt/noticias/redacao /2020/08/11/o-cearense-e-viking-estudo-reduz-carga-genetica-de-negro-e-indi gena-no-ce.htm. Acesso em: 1 dez. 2020.

POLLAK, Michael. Memória, Esquecimento, Silêncio. Estudos Históricos, Rio de Janeiro: CPDOC-FGV, vol. 2, n. 3, pp. 3-15, 1989.

PUNTONI, Pedro. A Guerra dos Bárbaros: povos indígenas e a colonização do sertão nordeste do Brasil, 1650-1720. São Paulo: EDUSP: Hucitec, 2002.

RODRIGUES, André Victor. Todo dia é dia do Índio: Quais são os povos indígenas do Ceará? 16 abr. 2019. Disponível em: https://www.ceara.gov.br/2019/04/16/tododia-e-dia-de-indio-quais-sao-os-povos-indigenas-do-ceara/\#: :text=Atrav\% C3\%A9s\%20deles\%20o\%20que\%20ainda,\%2CTubiba\%2DTapuia\%20e\%20 Tupinamb\%C3\%A1. Acesso em: 2 dez. 2020.

SANTOS, Luís Sérgio. O Cearense Revelado: uma jornada via DNA desvenda nossa ancestralidade. Fortaleza: Instituto Myra Eliane, 2020.

SILVA, Isabelle Braz Peixoto da. O Relatório Provincial de 1863 e a expropriação das terras indígenas. In: OLIVEIRA, João Pacheco de (Org.). A presença indígena no Nordeste: processos de territorialização, modos de reconhecimento e regimes de memória. Rio de Janeiro: Contra Capa, 2011a. p. 327-345.

SILVA, Pedro Alberto de Oliveira. História da escravidão no Ceará: das origens à extinção. Fortaleza: Instituto do Ceará, 2011b. 
THOMPSON, Edward Palmer. A miséria da teoria ou um planetário de erros: uma crítica ao pensamento de Althusser. Rio de Janeiro: Zahar editores, 1981.

VALIM, Patrícia; AVELAR, Alexandre de Sá. Negacionismo Histórico: entre a governamentalidade e a violação dos direitos fundamentais. 3 set. 2020. Disponível em: https://revistacult.uol.com.br/home/negacionismo-historico/. Acesso em: 5 dez. 2020.

VIDAL-NAQUET, Pierre. Os assassinos da memória: um Eichmann de papel e outros ensaios sobre o revisionismo. Campinas: Papirus, 1988.

\section{NOTAS}

${ }^{1}$ Cf. Origem Do Povo..., 2020 e Philippe, 2020.

${ }^{2} \mathrm{O}$ grupo conservador Brasil Paralelo, formado por "jovens empresários" marcadamente influenciados ideologicamente pelo astrólogo Olavo de Carvalho, tem produzido documentários que justificam as práticas de tortura durante a Ditadura Militar de 1964 ou relativizam os danos da escravidão, material que chegou a ser exibido na TV Escola. O seu canal no YouTube possui cerca de 1,64 milhão de inscritos. Já o canal da Associação Nacional de História (ANPUH - Nacional), principal entidade da comunidade de historiadores no Brasil, na mesma plataforma, possui aproximadamente 6,43 mil inscritos. Cf. Brasil Paralelo; ANPUH-Brasil.

${ }^{3}$ Fundado em 1887, por advogados, professores, jornalistas e comerciantes letrados de Fortaleza, mesclando abordagens evolucionistas e o método de crítica documental. Sua matriz discursiva acabou fazendo apologia à colonização portuguesa. A instituição foi responsável por elaborar narrativas históricas sobre as origens do Ceará e o éthos do povo cearense. Cf. Oliveira, 2001.

${ }^{4}$ O Grupo Edson Queiroz é um dos conglomerados empresariais mais poderosos do Ceará. No ramo das comunicações, é proprietário do Sistema Verdes Mares, composto por canal de TV, associado à Rede Globo, canais de Rádio e o Diário do Nordeste, um dos jornais impressos mais tradicionais do Estado. O Grupo também controla empresas nos seguintes ramos: água mineral; gás natural, eletrodomésticos, entre outros. Em seus planos de expansão, o "banco de terrenos do Edson Queiroz conta com pelo menos 300 imóveis [...] houve um grande esforço para regularizá-los nos últimos anos. Em um desses terrenos, localizado em Aracati (CE), na divisa com o Rio Grande do Norte, o grupo identificou elevado potencial para produção de energia eólica." (Falcão, 2018). Como destaca o Valor Econômico, uma das áreas de interesse dos Queiroz é a cidade de Aracati, litoral leste do Ceará, localizada na foz do Rio Jaguaribe, nas mesmas ribeiras onde, entre o fim do século XVII e o início do XVIII, houve uma série de conflitos envolvendo colonos portugueses e mercenários bandeirantes contra povos indígenas, com o objetivo de "limpar o terreno" para a expansão da pecuária, eventos conhecidos como a "A Guerra dos Bárbaros" (Puntoni, 2002). 
${ }^{5}$ São elas: "Parte Um - Como tudo começou"; "Parte Dois - De onde viemos"; e "Parte Três - Personagens, campo, pedaços da memória e DNA".

${ }^{6}$ Há ainda outro capítulo abordando um sexto bolsão genético que participa da composição genética cearense, a saber, “Arábia: judeus, sírios e libaneses” (Santos, 2020, pp. 215-221).

${ }^{7}$ Em 2019, dos 9.166.913 milhões de habitantes do Ceará, 4.186.221, ou seja, 45,7\% estavam localizados na grande Fortaleza. Cf. Pádua Martins, 2021.

${ }^{8}$ Tokenismo, do inglês tokenism, foi usado pela primeira vez por Martin Luther King e deriva de token (símbolo). Desde King, esse termo se refere às manobras para forjar a representatividade. Bastante empregado no mercado publicitário, em campanhas e peças com imagens que incluem, por exemplo, uma única negra ou um único latino para aparentar diversidade, o tokenismo tem servido para disfarçar a discriminação e a sub-representatividade de populações politicamente minoritárias (Jennings, 2004).

${ }^{9}$ Segundo o Plano da Igualdade Racial de Fortaleza, em 2016, a população negra (pardos e pretos) da cidade era estimada em 63\%. Cf. Fortaleza 2040: Publicações.

${ }^{10}$ Parsifal Barroso sentiu-se influenciado por Gilberto Freyre desde a palestra "Precisa-se do Ceará”, proferida em Fortaleza, em 28 de agosto de 1944. Nela, o pernambucano argumentou que: "A história do cearense deve ser traçada sob o critério mais dinamicamente transregional de que seja capaz um historiador social ou sociólogo especializado do estudo histórico da miscigenação. [...]. É uma história que ainda nem siquer [sic] se esboçou" (Freyre, 1944, p. 4). Em 1983, Freyre publicou um artigo retomando reflexões sobre o cearense e revelou ter recebido de Barroso a sugestão para uma "nova publicação de Precisa-se do Ceará” (Freyre, 1983, p. 11). Contudo, apesar da inspiração, Barroso está mais próximo do cientificismo racista do século XIX, pois Freyre tem certa sofisticação, ao menos metodológica, chegando a problematizar as motivações da emigração cearense: "melhoradas, porém, as condições de vida e aumentadas as oportunidades de êxito, no próprio Ceará, continuará o cearense a emigrar [...] por esses outros Estados? Continuará a haver um cearense nômade, 'cigano', 'judeu', ou tais características, tidas por alguns como fixas, vêm sendo condicionadas [...] pelas precárias condições de vida e pelas dificuldades de êxito que se vêm lentamente e até periodicamente contra ele [...] no seu Estado ou na sua Província?” (Freyre, 1983, pp. 22-23). O artigo de 1983 não poderia repercutir na edição de O Cearense, em 1969, mas poderia constar na "continuidade" da obra. Infelizmente, $O$ Cearense Revelado (Santos, 2020) também permanece mais vinculado ao pensamento do século XIX, repaginado com a utilização do DNA.

${ }^{11}$ Ao ser induzido por Santos a comentar a prevalência de genes da Fennoscandia no DNA de cearenses, o próprio geneticista Eran Elhaik, em sua participação on-line durante o lançamento de $O$ Cearense Revelado, rebateu que a porcentagem média de $11 \%$ de prevalência de genes da Fennoscandia encontrados no Ceará é igual à de Portugal, o que não pode ser considerado um alto valor. Para Elhaik, somente valores superiores a 50\% poderiam causar surpresa. Ou seja, Luís Santos e Igor Barroso é que decidiram enfatizar a preponderância do bolsão genético Fennoscandia entre os cearenses.

${ }^{12}$ A disposição de informações no capítulo 15 não segue nenhuma padronização. Os oito 
primeiros perfis apresentam um maior destaque, com trajetórias familiares, profissionais e detalhamento da carga genética. Outros indicam somente as iniciais do indivíduo em quem a coleta foi realizada, sem identificar profissão ou detalhes da carga genética. Entre os perfis destacados, consta o ex-governador Gonzaga Mota, descendente da família Studart, de origem inglesa, e um descendente da Família Boris, de origem francesa. Os 19 perfis identificados, por ordem de exposição no livro, são: 1- José Luiza: 85 anos, da comunidade negra Caetanos, em Beberibe, prevalência de 37\% de genes de origem africana; 2Marcos Monte: 81 anos, de Sobral, advogado, com 15\% de genes da Fennoscandia; 3- Cacique Pequena: 75 anos, do Povo Jenipapo-Kanindé em Aquiraz, prevalência de 48,1\% de genes ameríndios, sem apontar a porcentagem específica dos bolsões considerados ameríndios: América Central, Oeste da Amazônia, Oeste da América do Sul, entre outros; 4Marcos Venícius Lopes: 86 anos, de Quixadá, de origem libanesa, ex-funcionário do Banco do Nordeste, prevalência de 16,3\% dos genes do Sudeste da Índia; 5- Gilmar de Carvalho: 71 anos, de Sobral, professor da Universidade Federal do Ceará (UFC), em Fortaleza, dominância de 12,1\% de genes da Fennoscandia; 6- Gonzaga Mota: 78 anos, de Fortaleza, ex-governador do Ceará e professor universitário da UFC em Fortaleza, prevalência de 16,1\% de genes da Fennoscandia; 7- Francisco Bandeira: sem idade informada, de Fortaleza, artista plástico, prevalência de $38,2 \%$ de genes ameríndios, sem detalhar a porcentagem específica e quais bolsões indígenas foram localizados; 8- Kiko-Bloc Boris: 54 anos, de Fortaleza, "profissional da comunicação", possui "uma herança genética europeia de 61,2\%", com prevalência de 17,7\% de genes da Fennoscandia, seguido por 9,3\% do bolsão genético da Sardenha, 8,7\% do País Basco, 8,6\% das Ilhas Órcades (Escócia), 7,3\% do Sul da França, entre outros bolsões genéticos europeus; 9- Renata da Silva Pereira: 27 anos, de Fortaleza, prevalência genética indígena de 18,8\%, da América Central; 10- N.V.O.: 30 anos, de Fortaleza, prevalência de $11,2 \%$ de genes da Fennoscandia; 11- V.M.S.S.: sem idade informada, de Pacatuba, prevalência de 12,8\% de genes da Fennoscandia; 12- Maria H. Q. da Silva: 45 anos, de Brejo Santo, prevalência genética indígena de 15,4\% do bolsão da América Central; 13- Francisco M. B. de Oliveira: 61 anos, de Fortaleza, prevalência de 13,1\% de genes do Sul da França; 14- Gutemberg de Figueiredo Marques: sem idade informada, de Senador Pompeu, prevalência de 15,4\% de genes da Sardenha; 15- Marcos Souza de Araújo: 23 anos, de Iguatu, prevalência de 14,4\% de genes da Fennoscandia; 16- Carolina A. Parente: 21 anos, de Fortaleza, prevalência de 15,1\% de genes da Fennoscandia; 17- Sebastião E. T.: 52 anos, de Apuiarés, prevalência de 12,7\% de genes do sul da França; 18- Camila C.M.S.: 32 anos, de Fortaleza, prevalência de 11,8\% de genes da Fennoscandia; 19- Ismia Kariny Correia da Silva Costa; 25 anos, de Fortaleza, prevalência de 12,5\% de genes da África Bantu e de áreas do Niger-Congo (Santos, 2020, p. 225-266).

${ }^{13} \mathrm{O}$ Sr. José Benedito dos Santos, ou José Luiza, como é conhecido, é morador da "localidade de Caetanos, no município de Beberibe, onde a pequena população é originalmente negra" (Santos, 2020, p. 226). A referida localidade, ainda que reconhecida como sendo de origem negra, não consta entre as 52 Comunidades Remanescentes de Quilombos (CRQs) reconhecidas, atualmente, no Ceará, pela Fundação Palmares. O DNA de José Luiza possui predominância de genes africanos, com $37 \%$, seguido por " $15 \%$ do bolsão genético da América Central" (Santos, 2020, p. 226). Vale destacar que, entre o escasso número de 19 
perfis identificados, em um universo já reduzido de somente 160 amostras de DNA, não é possível identificar nenhuma coleta realizada em Comunidades Remanescestes de Quilombos (CRQs) do Ceará, certificadas pela Fundação Palmares, nem em bairros pobres da periferia de Fortaleza ou do interior do Ceará.

${ }^{14} \mathrm{E}$. P. Thompson, analisando os procedimentos aos quais o historiador deve recorrer para interpretar as fontes históricas, argumenta que "a evidência histórica existe, em sua forma primária, não para revelar seu próprio significado, mas para ser interrogada por mentes treinadas numa disciplina de desconfiança atenta. [...] suas credenciais como fatos históricos devem ser examinadas: como foram registradas? Com que finalidade? Podem ser confirmados por evidências adjacentes?" (Thompson, 1981, p. 38, grifos nossos).

Artigo submetido em 15 de dezembro de 2020.

Aprovado em 14 de março de 2021. 